\title{
KAJIAN ELEMEN VISUAL ARSITEKTUR TERKAIT PERSEPSI ANAK USIA DINI TERHADAP BANGUNAN
}

\author{
Astrid Austranti Yuwono \\ Universitas Kristen Maranatha \\ astrid.ay@art.maranatha.edu
}

\begin{abstract}
Abstrak: Arsitektur ditujukan bagi penggunanya dengan pertimbangan jangka panjang. Sebuah arsitektur merupakan karya seni pakai yang tidak hanya menjadi milik pembuat karya namun juga melibatkan orang lain yakni pengguna dan pengamat. Usia dini pada proses pertumbuhan seorang manusia merupakan fase penting yang perlu mendapat perhatian khusus. Sedemikian pentingnya hingga muncul istilah The Golden Age. Salah satu jenis persepsi yang memiliki peranan penting pada masa pertumbuhan seorang anak adalah persepsi visual. Melalui persepsi visual, seorang anak belajar melihat perbedaan, persamaan, dan pengelompokan. Bangunan merupakan hasil perwujudan sebuah analisis terhadap pengguna, fungsi, dan gagasan. Anak usia dini merupakan salah satu dari pengguna yang perlu mendapatkan perhatian khusus. Seringkali pemahaman perancang terhadap apa yang dibutuhkan oleh seorang anak usia dini dan bagaimana kacamata seorang anak dalam melihat lingkungannya masih belum sepenuhnya diperhatikan. Penelitian ini menelaah elemen visual arsitektur yang memiliki peran lebih dominan diperhatikan oleh anak usia dini dengan dasar analisa teori persepsi. Metode yang digunakan terkait responden yang adalah anak usia dini yakni dengan meminta mereka menggambarkan bangunan berdasarkan persepsi masing-masing. Hasil yang didapatkan dalam penelitian ini adalah bahwa elemen visual arsitektur yang sudah dapat dipersepsikan kembali olah responden secara jelas adalah bentuk dan dimensi.
\end{abstract}

Kata kunci: anak usia dini, arsitektur, persepsi, sekolah, visual.

\begin{abstract}
Architecture is intended for users with long-term consideration. An architecture is a work of art that does not only belong to the creator of the work but also involves other people, users and observers. Early age in a human growth process is an important phase that needs special attention. It is also called as The Golden Age. One type of perception that has an important role in a child's growth period is visual perception. Through visual perception, a child learns to see differences, similarities, and groupings. The building is the result of the realization of an analysis of users, functions and ideas. Toddlers is one of the users who need special attention. Designer's understanding of what is needed by an early child and how a child's perspective in seeing their environment are still not fully addressed. This study examines architectural elements that have more dominant role to be considered by toddlers with the basis of perception theory. The method used in relation to respondents who are toddlers is to describe buildings based on their respective perceptions by drawing. The results obtained in this study is that the architectural elements that can be re-perceived by the respondent clearly are the shape and dimensions.
\end{abstract}

Keywords: toddler, architecture, perception, school, visual.

\section{PENDAHULUAN}

Sebuah karya arsitektur dirancang bagi penggunaanya dengan pertimbangan jangka panjang. Sebagai karya yang termasuk dalam kategori seni pakai, arsitektur tidak hanya menjadi milik pembuat karya saja, namun juga milik orang lain yaitu pengguna dan pengamatnya. Arsitektur merupakan sesuatu yang umum karena dibangun dan dipakai oleh banyak orang, tetapi juga bersifat personal karena respon tiap orang dapat berbeda secara spesifik satu sama lain (Laurens, 2004, p. 55). Respon setiap orang merupakan hasil dari persepsi saat seseorang menerima informasi dari lingkungan di luarnya. Salah satu tolok ukur keberhasilan sebuah karya arsitektur ditentukan oleh persepsi pencipta, pengguna dan pengamat. 
Pada tahun 2013 dalam Acara Penghargaan Kota Layak Anak sebagai peringatan Hari Anak Nasional, mantan Menteri Negara Pemberdayaan Perempuan dan Perlindungan Anak Republik Indonesia Linda Gumelar menyatakan bahwa di Indonesia belum ada kota yang layak tinggal bagi anak-anak walau beberapa kota sudah mulai menuju ke arah tersebut ("Indonesia Has No Child-Friendly Cities, Minister Says”, 2013). Saat ini sudah berangsur banyak kota yang diakui sebagai kota layak anak menuju Indonesia Layak Anak di tahun 2030. Arsitektur bangunan yang memiliki fungsi terkait dengan anak usia dini menjadi sangat penting karena termasuk pada lingkungan yang memiliki pengaruh terhadap eksplorasi seorang anak. Permasalahan yang muncul adalah kurangnya pelibatan pendapat anak usia dini terhadap perencanaan bangunan yang sebenarnya diperuntukan bagi mereka. Winston Churchill pernah menyatakan sebuah quote "We Shape our building; afterwards they shape us". Quote tersebut menunjukkan batapa pentingnya peran sebuah bangunan terhadap kehidupan penggunanya. Keselarasan antara perancang dengan pengguna dalam konteks ini anak usia dini menjadi penting untuk diselaraskan.

Kajian ini berupaya memperlengkapi pengetahuan mengenai Anak Usia Dini yang merupakan fase penting dimana seorang anak sedang dalam masa eksplorasi penuh terhadap segala hal yang mereka temui di sekitar mereka. Keseluruhan informasi tersebut kemudian menjadi pembelajaran bagi perkembangan kemampuannya. Kajian ini memiliki tujuan untuk menyatakan elemen-elemen penting terkait dengan arsitektur dalam persepsi anak usia dini dengan studi kasus sebuah sekolah taman kanak-kanak. Sekolah dipilih menjadi studi kasus karena memiliki unsur pendidikan di dalamnya, sehingga peran bangunan sebagai fasilitas sekaligus alat dalam pendidikan pun menjadi penting.

Persepsi dihasilkan oleh adanya rangsangan dari lingkungan di sekitar manusia yang ditangkap oleh panca indera. Panca indera yang paling cepat memberikan rangsangan adalah penglihatan. Arsitektur merupakan hasil karya yang dapat memberikan pengalaman ruang secara langsung melalui indera penglihatan. Elemen fisik dan karakteristik visual memiliki peran yang penting dalam membentuk persepsi visual manusia.

Persepsi yang dikemukakan oleh (Halim, 2005) merupakan proses dimana seseorang memperoleh informasi dari lingkungan sekitar yang dapat dipengaruhi oleh cara melihat suatu hal yang sama dapat berbeda karena dipengaruhi oleh keadaan. Aspek persepsi yang terkait dengan elemen visual adalah perhatian 'attention' dan rekognisi pola 'pattern of recognition' (Matlin, 2012). Dalam paparannya, Budiarti (2011) menyatakan bahwa atribut yang berperan dalam rekognisi sebuah obyek adalah bentuk, ukuran, warna, tekstur, dan orientasi.

Jenis perkembangan pada anak salah satunya adalah perkembangan kognitif. Seorang psikolog berkebangsaan Swiss, Jean Piaget menyatakan hasil observasinya bahwa seorang bayi pun sudah memiliki kesadaran akan keadaan sekitarnya, terlihat dari bagaimana seorang bayi memiliki kecenderungan untuk menjelajahi sekitarnya. Proses tersebut merupakan langkah awal perkembangan kemampuan, persepsi, dan kemampuan berpikir.

Teori Jean Piaget menyatakan tentang bagaimana seorang anak belajar yaitu bahwa supaya anak memahami sesuatu, ia harus menemukan dan membangun pengertian itu sendiri. Perkembangan potensi anak hendaknya dimulai sejak dini, oleh sebab itu perlu dipertimbangkan penggunaan prinsip-prinsip yang berorientasi pada kebutuhan anak.Proses belajar membutuhkan lingkungan yang kondusif, menyenangkan dan menarik bagi anak. 
Indera penglihatan menempati posisi vital dalam arsitektur, karena karya arsitektur dinikmati sebagai obyek yang memberikan sensasi langsung pada mata (Halim, 2005). Dalam proses pemahaman akan sebuah ruang, karakteristik visual menjadi informasi penting yang dibaca, disimpan, dan diingat tentang sebuah tempat. Karakteristik visual dipengaruhi oleh bentuk/rupa/wujud, warna, tekstur, penerangan/pencahayaan, proporsi, skala (Ching, 1996).

Tekstur adalah kualitas tertentu suatu permukaan yang timbul sebagai akibat dari struktur tiga dimensi (Ching, 1996). Tekstur digunakan untuk menyatakan kualitas permukaan material sehingga dapat memberikan nilai tertentu pada sebuah permukaan. Indra penglihatan dan sentuhan sangat berkaitan erat. Saat melihat sebuah tekstur, saat itu juga seolah-olah kualitas permukaan tersebut dapat dirasakan tanpa perlu menyentuhnya. Hal tersebut berkaitan dengan pengalaman terdahulu mengenai tekstur yang sejenis.

Skala, jarak pandang, dan cahaya merupakan faktor penentu yang mempengaruhi persepsi terhadap tekstur. Semakin jauh posisi pengamat terhadap tekstur, sekasar apapun tekstur yang sebenarnya, akan terlihat halus penampilannya, dan sebaliknya. Skala akan mempengaruhi penampilan dan posisi tekstur dalam sebuah ruang tekstur dapat membuat seolah-olah sebuah ruang terlihat lebih kecil, lebih dekat, mengurangi maupun menambah bobot visualnya. Arah datangnya cahaya terhadap tekstur juga mempengaruhi persepsi pengamat terhadap kualitas tekstur. Pencahayaan yang menyebar cenderung mengurangi tekstur fisiknya.

Sebagaimana bentuk dan tekstur, sifat dasar visual lainnya adalah warna. Dudek (1996:110) menyatakan bahwa warna dianggap memiliki peran yang penting dalam sebuah fasilitas anak usia dini berdasarkan fakta bahwa anak-anak sudah dapat menerima dan mengembangkan pemahaman mereka akan warna. Warna yang tampak pada benda bersumber pada cahaya yang menyinari benda tersebut. Warna dapat digunakan untuk memperkuat sebuah pesan dengan cara membuatnya menjadi kontras terhadap warna disekitarnya. Setiap karakter warna memiliki kecenderungan efek psikologis yang ditimbulkannya. Warna-warna yang cerah dan hangat cenderung mengembang dan memperbesar ukuran aktual sebuah obyek, terutama jika benda diposisikan di sebuah latar belakang yang gelap. Oleh karena itu, warna-warna dengan karakter ini dapat digunakan untuk meningkatkan kesan lega suatu ruang. Sebaliknya karakter warna gelap dan pekat akan cenderung memberi kesan dekat, memperpendek jarak, mengurangi skala sebuah ruang.

Ching (1979) juga memaparkan bahwa cahaya yang memasuki ruang melalui bukaan turut menghidupkan tidak saja hanya warna dan menegaskan tekstur, namun juga menegaskan bentuk-bentuk yang ada melalui intensitas dan distribusinya dalam sebuah ruang. Cahaya juga dapat menciptakan suasana ruangan, membuat peralihan menuju suasana yang baru. Dengan demikian, besar dan letak bukaan akan memiliki peran dalam menentukan orientasi penerimaan cahaya masuk ke dalam bangunan.

Proporsi menyangkut hubungan suatu bagian dengan bagian yang lain atau dengan keseluruhannya, dapat berupa besaran, kuantitas, dan tingkatan (Ching, 1996:131). Proporsi merupakan salah satu pertimbangan visual yang penting. Keputusan mengenai proporsi didasarkan juga atas pertimbangan estetik, pertimbangan visual dari korelasi 'dimensi' yang diinginkan atara komponen-komponen dan sebagian dan seluruhnya dari sebuah bangunan (Ching, 1979:296). 
Prinsip desain mengenai skala berkaitan dengan proporsi, dimana keduanya juga berkaitan dengan ukuran relasi dari benda-benda. Skala lebih berbicara khusus tentang ukuran sesuatu relatif terhadap standar yang sudah diketahui. Skala visual adalah besarnya sesuatu yang tampak ketika diukur terhadap benda-benda di sekitarnya. elemen yang memiliki skala tidak lazim biasanya digunakan untuk menjadi point of interest sekaligus menegaskan sesuatu. Selain itu skala jika dikaitkan dengan manusia akan menentukan apakah sebuah ruang sudah memberikan persepsi yang nyaman. (Ching, 1996:136-138).

Kajian ini dilakukan berdasarkan pemahaman akan elemen dasar arsitektur (Ching, 1979) dan persepsi visual manusia (Halim, 2005). Melalui temuan elemen visual yang berperan penting terkait persepsi anak usia dini diharapkan dapat memberikan salah satu dasar ilmiah terhadap keputusan-keputusan perancangan fasilitas anak. Lingkup kajian difokuskan pada upaya menemukan hal-hal yang dipersepsikan anak usia dini tentang bangunan secara visual dengan kerangka konseptual pada Gambar 1.

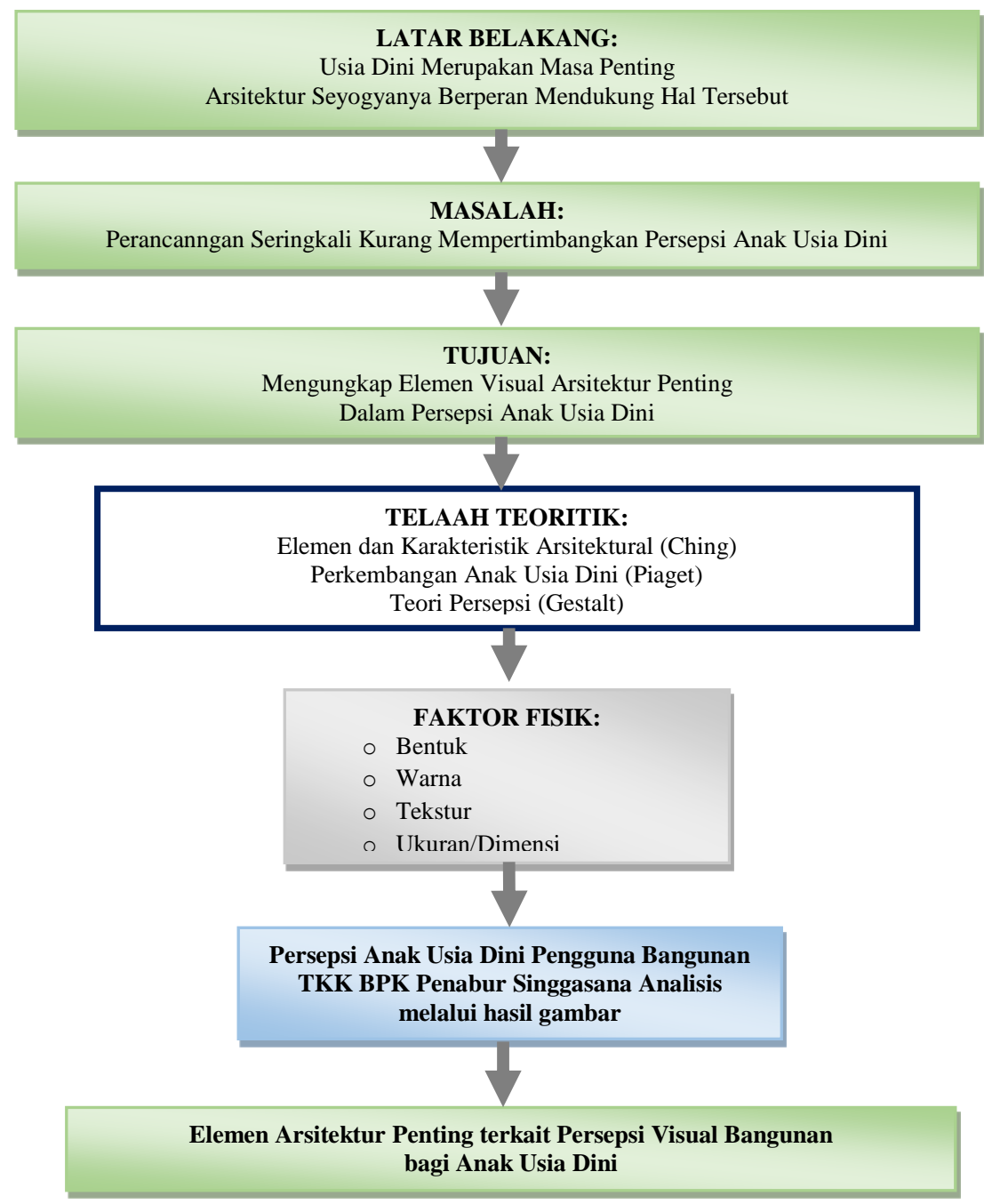

Gambar 1. Kerangka Konseptual 


\section{STUDI KASUS DAN METODE PENELITIAN}

Studi kasus yang digunakan adalah sebuah sekolah yang secara desain arsitekturnya sudah mencoba mewujudkan bangunan yang memiliki citra bentuk fasilitas bagi anak-anak. Kajian literatur didapatkan bahwa atribut yang berperan dalam rekognisi sebuah obyek adalah bentuk, ukuran, warna, tekstur, dan orientasi. Bangunan yang menjadi obyek kasus adalah sebuah bangunan sekolah taman kanak-kanak di Komplek Singgasana Pradana Bandung. Sekolah ini memiliki bangunan yang cukup unik, terdiri dari bangunan utama yang berbentuk dasar tabung.
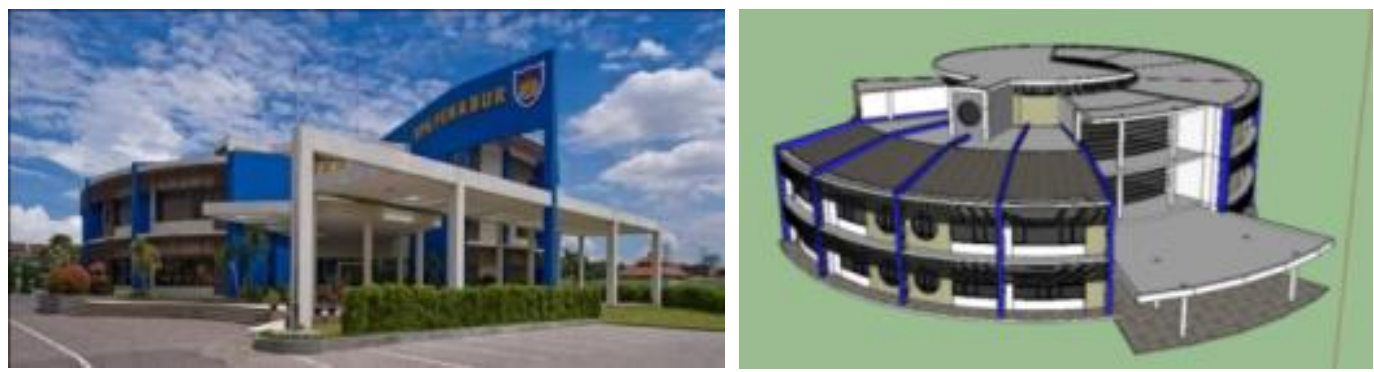

Gambar 2. Bangunan sekolah TKK BPK Penabur Singgasana-Bandung Sumber: F-Architect (2013)

Bentuk dasar tabung tersebut dengan demikian membuat bangunan menjadi massa yang sangat besar dari segi ukuran. Warna dominan yang dimiliki bangunan tersebut adalah warna biru dan putih. Tekstur dalam jarak dekat tidak terlalu bervariasi terkait desain, lebih banyak terkait fungsi dan keamanan bagi anak usia dini. Namun, jika dilihat dalam skala yang lebih besar tekstur dapat dibaca melalui bentuk dan posisi-posisi bukaan pada bangunan. Sementara itu, orientasi dapat terasa dengan adanya penekanan bentuk penutup atas atau pun bukaan-bukaan.

Rentang usia anak usia dini yakni 2-6 tahun belum memiliki kemampuan komunikasi lisan yang cukup lengkap dalam mengungkapkan pemikirannya. Oleh karena itu dalam kajian ini digunakan metode eksperimental dengan menggunakan gambar sebagai alat komunikasi. Metode eksperimental menurut Wang (2013) berusaha mencari hubungan antara beberapa variabel. Dalam penelitian ini, responden akan diminta untuk menggambarkan secara bebas bangunan sekolah mereka. Hasil penggambaran bangunan tersebut kemudian akan dikaji lebih lanjut untuk menemukan hubungan antara persepsi mereka dengan elemen apa yang dipersepsikan.

Metode kualitatif interpretivisme (Wang, 2013) juga digunakan juga dalam kajian ini yakni melalui proses pengumpulan data dan reduksi data hingga mendapatkan hasil, temuan serta kesimpulan. Hasil penggambaran anak usia dini tentang bangunan sekolahnya kemudian diinterpretasikan oleh Penulis terkait aspek penting persepsi anak usia dini tentang bangunan.

Teknik penelitian yang dilakukan untuk mendapatkan data-data analisis di lapangan adalah dengan meminta anak-anak usia dini yang menjadi responden untuk menggambarkan bangunan sekolah mereka sesuai dengan persepsi masing-masing. Proses penggambaran dilengkapi dengan wawancara singkat untuk mendapatkan informasi pelengkap terkait hasil gambar. 


\section{HASIL DAN TEMUAN}

Berikut adalah ringkasan hasil interpretasi Penulis terhadap hasil-hasil gambar siswa usia dini TKK BPK Penabur Singgasana Bandung.

Tabel 1. Hasil Karya Tingkat Usia 4-5 Tahun

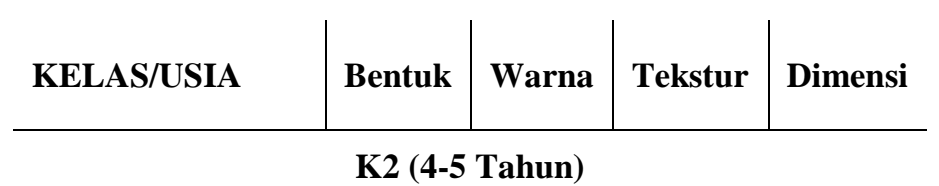

\begin{tabular}{l|c|c|c|c}
\hline Kenneth & $\times$ & $\times$ & $\times$ & $\sqrt{ }$ \\
\hline Lionard & $\times$ & $\times$ & $\times$ & $\sqrt{ }$ \\
\hline Ainslie & $\times$ & $\times$ & $\times$ & $\sqrt{ }$ \\
\hline Stacy & $\times$ & $\times$ & $\sqrt{ }$ & $\sqrt{ }$ \\
\hline Rionardo & $\sqrt{ }$ & $\times$ & $\times$ & $\sqrt{ }$ \\
\hline Sherryl & $\sqrt{ }$ & $\times$ & $\sqrt{ }$ & $\sqrt{ }$
\end{tabular}

Tabel 2. Hasil Karya Tingkat Usia 5-6 Tahun

\begin{tabular}{l|c|c|c|c} 
KELAS/USIA & Bentuk & Warna & Tekstur & Dimensi \\
\hline \multicolumn{5}{|c|}{ K3 (5-6 Tahun) } \\
\hline Hansen & $\times$ & $\times$ & $\times$ & $\sqrt{ }$ \\
\hline Kenzie & $\times$ & $\times$ & $\times$ & $\sqrt{ }$ \\
\hline Vincent & $\sqrt{ }$ & $\times$ & $\times$ & $\sqrt{ }$ \\
\hline Aimee & $\sqrt{ }$ & $\times$ & $\sqrt{ }$ & $\sqrt{ }$ \\
\hline Sheeren & $\sqrt{ }$ & $\times$ & $\sqrt{ }$ & $\sqrt{ }$ \\
\hline Livia & $\sqrt{ }$ & $\times$ & $\sqrt{ }$ & $\sqrt{ }$
\end{tabular}

Dari hasil tersebut di atas, maka secara kuantitatif didapatkan jumlah elemen yang tergambarkan oleh responden.

Tabel 3. Jumlah Persepsi Arsitektural yang tergambarkan oleh Responden

\begin{tabular}{l|c}
$\begin{array}{l}\text { Karakteristik } \\
\text { Visual }\end{array}$ & Jumlah \\
\hline Bentuk & 6 of 12 \\
\hline Warna & 0 of 12 \\
\hline Tekstur & 5 of 12 \\
\hline Dimensi & 12 of 12
\end{tabular}

Pemahaman akan dimensi bangunan oleh responden sangat terlihat, yaitu dengan digambarkannya bangunan yang tinggi ataupun yang melebar dengan ukuran yang jauh berbeda dengan obyek-obyek lain yang mereka gambarkan. Bahkan ada yang sudah sangat 
memahami jumlah lantai yang ada di bangunan sekolahnya. Hal tersebut menunjukan pemahaman responden juga terkait persepsi bentuk dan dimensi yang dapat ditangkap dan dikomunikasikan kembali oleh anak usia dini.

Jika diamati, bentuk ditunjukan oleh responden dengan membuat proporsi bangunan memanjang sebagai hasil penangkapan mereka akan bentuk bangunan yang melingkar (menerus). Sementara tekstur yang responden gambarkan adalah terkait dengan bentuk, terutama bentuk jendela, sehingga dapat disimpulkan bahwa tekstur yang terkait dengan bentuk memiliki pengaruh kuat dalam persepsi responden. Dengan kata lain bentuk detil yang karena dimensinya lebih kecil sehingga lebih mudah dikenali oleh anak usia dini.

Elemen warna justru ternyata tidak terlalu responden hiraukan kesamaannya. Pemilihan warna cenderung subyektif berdasarkan warna yang disuka oleh masing-masing. Warna memang menjadi identitas bangunan, namun pada hasil kajian ini tidak sekuat peran bentuk. Pemaknaan warna tidak menjadi penentu dalam pemilihannya. Pertimbangan pemilihan warna digunakan oleh responden, namun tidak dijadikan alat untuk mengkomunikasikan identitas yang mereka temukan dari bangunan. Bangunan hanya memiliki sedikit warna (aksen biru, broken white, dan warna-warna berdasarkan material lainnya), sementara hasil penggambaran responden tentang bangunan justru menggunakan media tulis yang berwarna-warni. Hal tersebut menunjukkan bahwa responden membutuhkan warna untuk mengkomunikasikan apa yang ada di pikirannya namun tidak menyertakan makna tertentu yang didalamnya.

\section{DISKUSI/PEMBAHASAN}

Melalui dasar interpretasi penulis dilakukan komparasi dengan hasil gambar responden yang sudah dipilih berdasarkan hasil penelitian Kerschensteiner (Zulkifli, 2009, p. 44) yakni hanya peserta didik usia 4-5 tahun dan usia 5-6 tahun saja yang menjadi responden, dengan jumlah masing-masing tingkat usia adalah 6 responden. Dari setiap gambar responden kemudian diamati karakteristik visual apa saja yang mereka pakai untuk mengkomunikasikan pemahaman mereka tentang bangunan sekolahnya. Berikut akan dikemukakan contoh interpretasi hasil gambar anak usia dini oleh penulis.

Di bawah ini adalah karya-karya dari 3 (tiga) responden berusia 4-5 tahun yang dalam penggambarannya tidak menyatakan bentuk warna, maupun tekstur. Kedua gambar ini diinterpretasikan penulis sebagai ungkapan adanya sebuah dimensi yang besar terlihat dari proporsi gambar terhadap kertas (gambar kiri) serta keadaan dimana beberapa obyek digambarkan berada di dalam sebuah ruang (gambar kanan). Sedangkan pada gambar bawah terlihat responden berusaha menggambarkan sesuatu yang jauh lebih besar ukurannya dibandingkan dengan obyek-obyek lainnya yang ia gambarkan. 

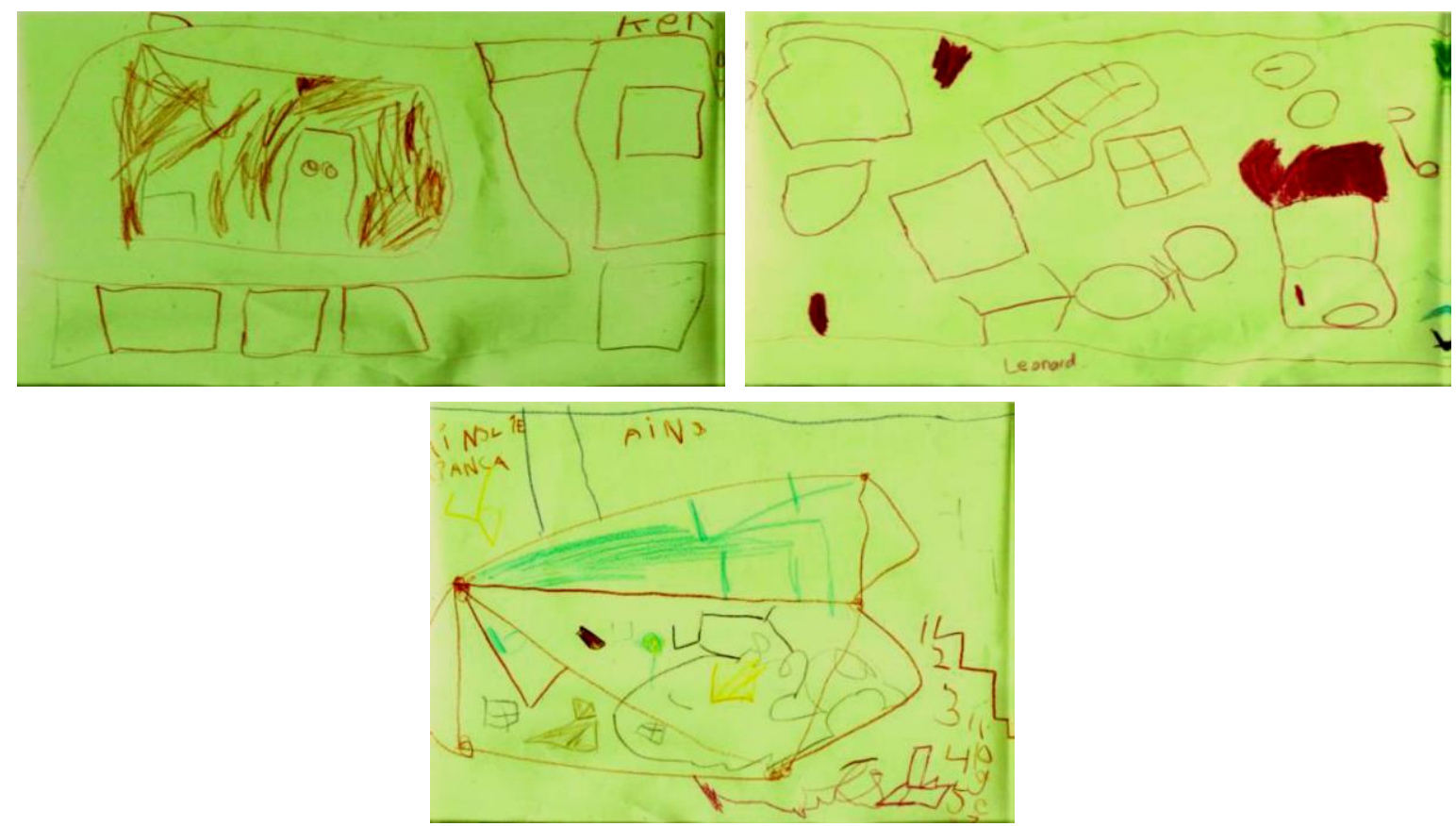

Gambar 3. Karya Kenneth (K2_4-5 Tahun) menggambarkan Dinding, Jendela, Pintu (kiri); Karya Leonard (K2_4-5 Tahun) menggambarkan Dinding, Jendela, Orang (kanan); Karya Ainslie (K2_4-5 Tahun) menggambarkan Dinding, Atap, Jendela, Tangga, Mobil (bawah)

Pada tingkat usia lebih tinggi pun yaitu 5-6 tahun, ternyata ditemukan pengambaran persepsi anak usia dini yang juga 'hanya' mengkomunikasikan dimensi dari bangunan sekolahnya. Kedua gambar di bawah ini sama sekali tidak memberikan informasi mengenai bentuk, warna, maupun tekstur yang mendekati kondisi fisik bangunan sebenarnya.
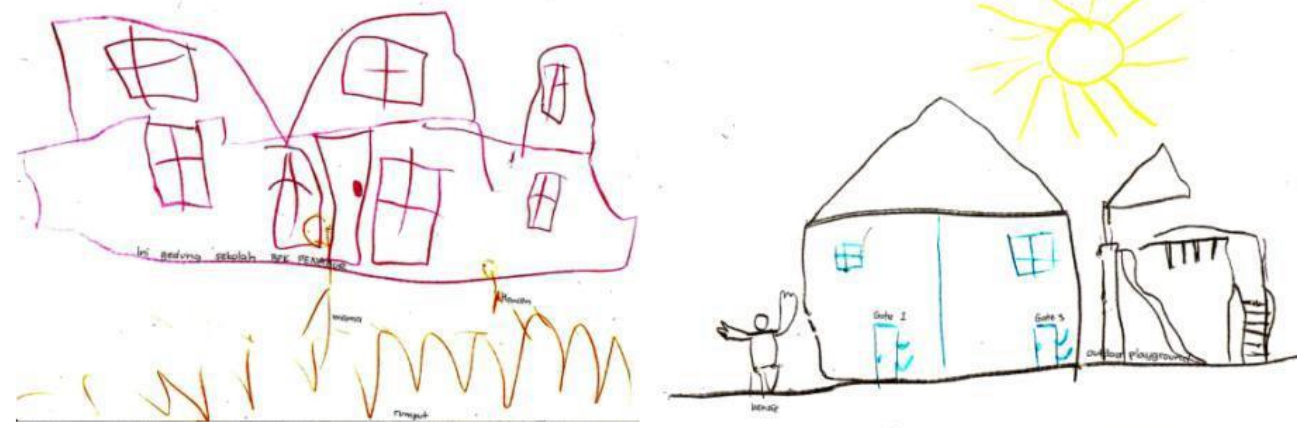

Gambar 4. Karya Hansen (K3_5-6 Tahun) menggambarkan Dinding, Atap, Jendela, Pintu, Taman, Orang (kiri); Karya Kenzie (K3_5-6 Tahun) menggambarkan Dinding, Atap, Jendela, Pintu, Playground, Orang (kanan)

Hasil penggambaran, di tingkat usia 4-5 tahun, yang dapat diinterpretasikan oleh penulis memiliki 2 aspek yaitu tekstur dan dimensi terdapat pada karya berikut. Hasil penggambaran anak usia dini di bawah ini memiliki elemen tekstur karena responden menggambarkan varian bentuk jendela yaitu lingkaran dan persegi, sedangkan dimensi digambarkan dengan banyaknya 'jendela-jendela'. Elemen bentuk bangunan sama sekali tidak terlihat pada karya ini. 


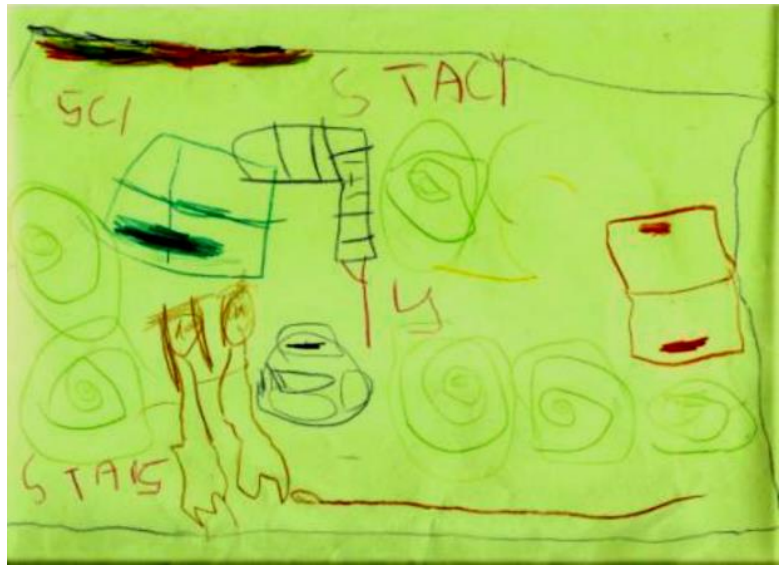

Gambar 5. Karya Stacy (K2_4-5 Tahun) menggambarkan Dinding, Jendela, Pintu, Orang

Karya lainnya dari tingkat usia 4-5 tahun yang memiliki 2 elemen yaitu bentuk dan dimensi adalah karya Rionard (K2_4-5 Tahun). Karya ini memberi gambaran bentuk juga dengan membuat bentuk jendela yang 'berbaris' menerus seolah menunjukan bentuk tak terputus sebuah lingkaran. Elemen dimensi digambarkan dengan proporsi gambar yang melebar ke samping menunjukan sesuatu yang besar.

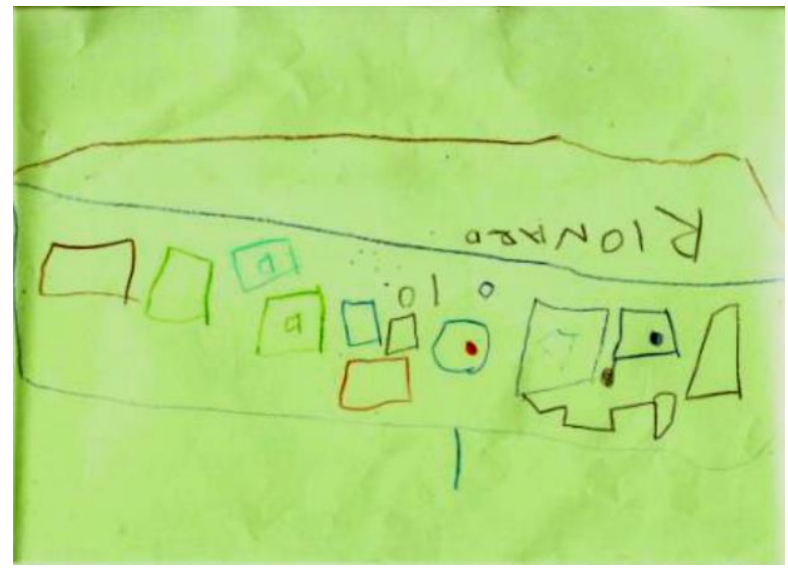

Gambar 6. Karya Rionard (K2_4-5 Tahun) menggambarkan Dinding, Atap, Jendela, Pintu

Pada gambar hasil karya Sheryl yang berusia sekitar 4-5 tahun di bawah ini, dapat terlihat bagaimana pemahamannya tentang bangunan TKK BPK Penabur Singgasana Bandung. Interpretasi penulis yang didukung oleh hasil percapakan sederhana dengan Sheryl adalah bahwa Sheryl membuat bentuk jendela yang khas sebagai pemahamannya akan bentuk pada kulit bangunan sebagai tekstur yang menjadi identitas bangunan sekolahnya. Pola jendela yang dibuat berulang secara menerus menunjukan pemahamannya akan ruang yang berbentuk lingkaran yang cenderung tidak memiliki titik henti. Hal tersebut juga menunjukan pemahamannya akan bangunan yang memiliki dimensi yang besar, sehingga Sheryl harus menggambarkan sedemikian panjangnya. Pemilihan warna dalam menggambarkan bangunan sekolahnya tidak mencirikan sedemikian pentingnya warna biru yang secara kuat dan konsisten diterapkan oleh bangunan TKK BPK Penabur Singgasana Bandung ini. Seperti pada karya- 
karya sebelumnya, pemilihan warna lebih kepada kesukaannya akan warna merah, tanpa memperdulikan kesamaan warna yang Sheryl pilih dengan yang ada pada bangunan.

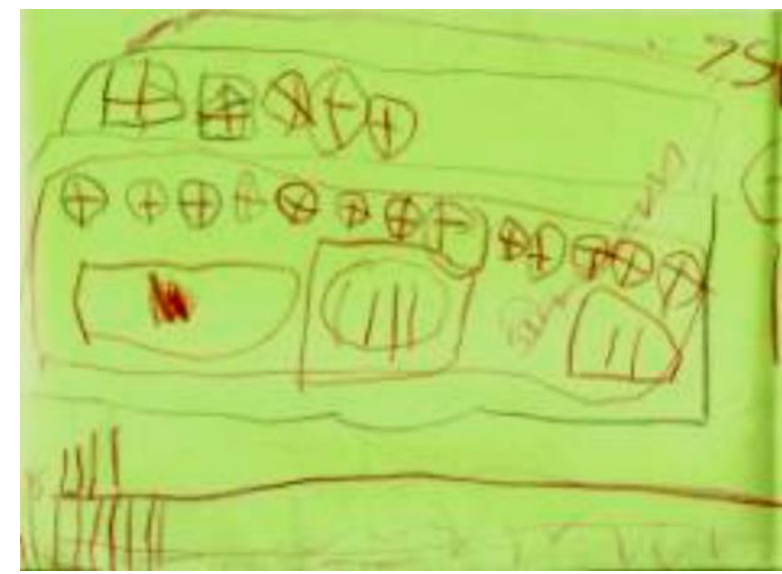

Gambar 7. Karya Sheryl (K2_4-5 tahun) menggambarkan Dinding, Atap, Jendela, Tangga, Pagar

Karya-karya pada itngkat usia 5-6 tahun yang diinterpretasikan Penulis memiliki 3 aspek yaitu bentuk, tekstur, dimensi ditemukan juga pada 4 (empat) karya berikut. Pada hasil karya Vincent (K3_5-6 Tahun) menunjukkan pemahamannya akan bentuk dan dimensi sudah lebih jauh ke dalam visualisasi ruang 3 dimensi. Karya ini menggambarkan ruang dalam bangunan yang terdiri dari lapisan lantai-lantai dari lantai bawah sampai ke lantai atas. Lapisan-lapisan tersebut juga menunjukkan elemen dimensi tinggi (besar). Elemen tekstur meskipun berbeda dari kebanyakan karya yang menggambarkan jendela, karya ini justru menunjukan detil kipas angin yang memang ada pada bangunan sekolah tersebut.

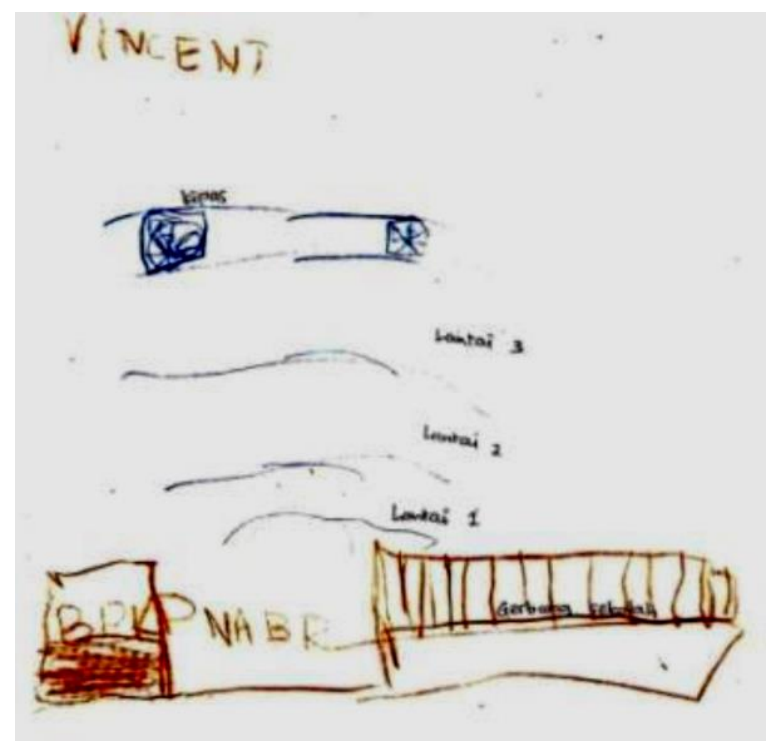

Gambar 8. Karya Vincent (K3_5-6 Tahun) menggambarkan Jumlah Lantai, Kipas Angin, Pagar, Signage 
Pada 3 (tiga) hasil karya berikut secara umum ditemukan 3 elemen yaitu bentuk, dimensi, dan tekstur. Proporsi bangunan yang digambarkan merupakan pemahaman akan bentuk bangunan yang tinggi. Tekstur digambarkan dengan membuat sejumlah jendela yang tersusun pada dinding bangunan. Dimensi ditunjukan terkait pada proporsi terhadap penggambaran lingkungan sekitar bangunan yang jauh lebih kecil. Namun ketiga gambar tersebut tidak memiliki informasi yang erat kaitannya dengan bangunan obyek studi kasus yaitu bangunan TKK BPK Penabur Singgasana Bandung.
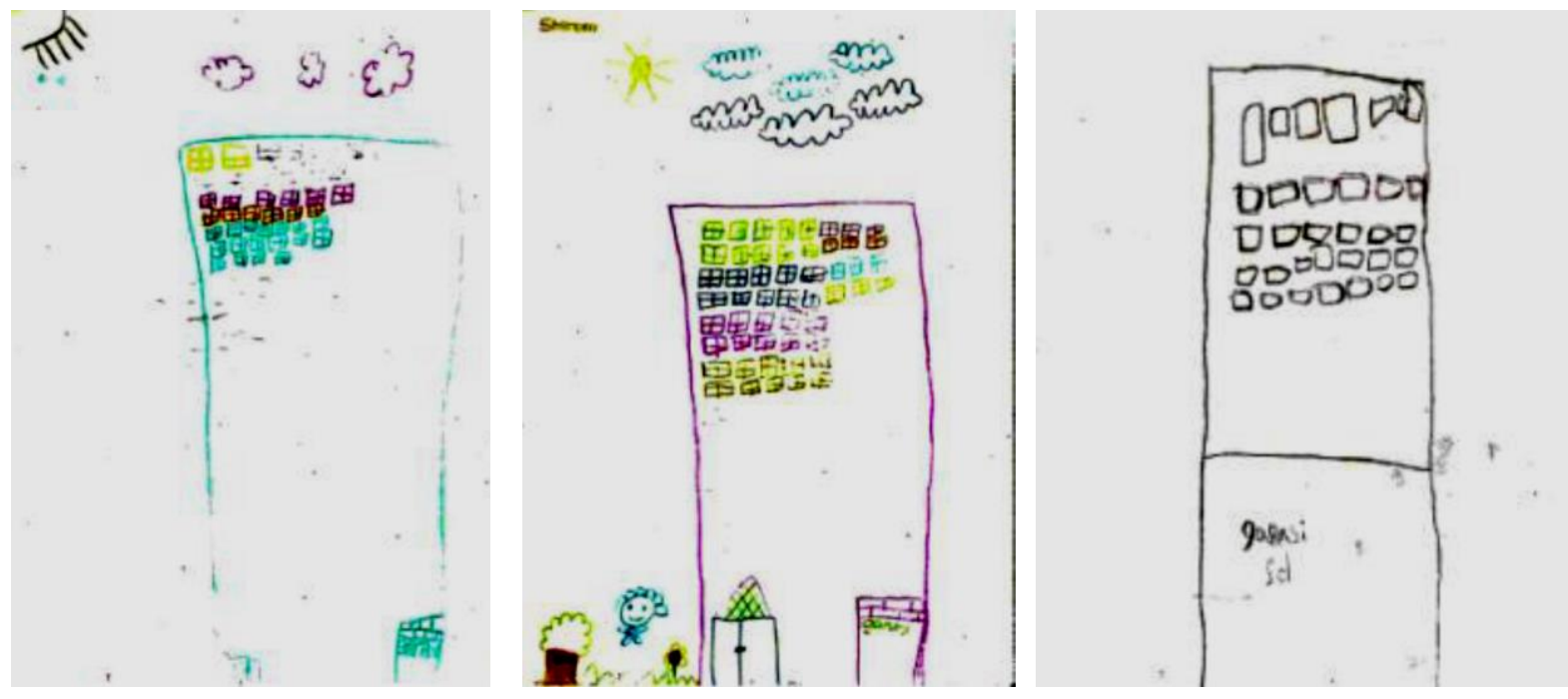

Gambar 9. Karya K3_5-6 Tahun Karya Aimee (kiri) \& Karya Sheeren (tengah) menggambarkan Dinding, Jendela, Pintu, Garasi; Karya K3_5-6 Tahun Karya Livia (kanan) menggambarkan Dinding, Jendela, Garasi

\section{KESIMPULAN}

Dalam kajian ini peran indera yang diamati terkait persepsi adalah indera visual. Arsitektur merupakan produk yang dikenali mula-mula melalui elemen visual/fisiknya. Persepsi terhadap sebuah obyek dihasilkan oleh pengamatan terhadap karakteristik visual yaitu melalui bentuk, warna dan tekstur, serta dimensi. Keempat elemen tersebut merupakan elemen yang mudah dikenali anak usia dini berdasarkan tahap perkembangannya. Elemen terkuat yang dikenali dan dikomunikasikan kembali oleh anak usia dini dalam penelitin ini (melalui metode menggambar) adalah bentuk dan dimensi.

Pada skala besar, yaitu massa bangunan, bentuk dan dimensi dapat memberikan identitas untuk sebuah bangunan. Dalam kasus obyek studi dalam penelitian ini, bentuk lingkaran yang berbeda dari bentuk bangunan sekolah tingkat pendidikan lanjut (bentuk persegi), dengan jelas menunjukan bahwa bangunan ini memiliki fungsi dan sifat-sifat penggunaan yang berbeda.

Dalam kaitannya dengan anak usia dini, bentuk harus dapat dipahami oleh mereka agar sasaran pendidikan tercapai (terkait obyek studi yang adalah sebuah bangunan fasilitas pendidikan). Oleh karena itu, bentuk dan dimensi dalam skala kecil juga harus diterapkan. Pada kasus obyek studi, konsistensi dalam memperkuat bentuk diterapkan melalui pola lantai, bentuk dinding dan 
atap/langit-langit. Sementara itu dimensi bangunan yang besar cenderung terlalu dominan bagi anak usia dini.

Penelitian ini dapat dilakukan pada bangunan sekolah sejenis untuk mendapatkan gambaran menyeluruh terkait persepsi anak usia dini terhadap elemen desain. Penelitan ini juga dapat dilanjutkan dengan pendekatan wawancara terkait elemen desain dan persepsi yang diungkapkan oleh anak usia dini, untuk melihat lebih jauh bagaimana hubungan elemen desain tersebut dalam bangunan.

\section{DAFTAR PUSTAKA}

Budiarti, L. N. (2011). Psikologi Persepsi. Bandung: Penerbit ITB.

Halim, D. P. (2005). Psikologi Arsitektur. Jakarta: Grasindo.

Indonesia Has No Child-Friendly Cities, Minister Says. (24. July 2013). Tempo.co.

Laurens, J. (2004). Arsitektur dan Perilaku Manusia. Jakarta: Grasindo.

Matlin, M. W. (2012). Cognition, 8th Edition. New York: Wiley Global Education.

Wang, D. C. (2013). Architectural Research Methods. New York: John Wiley \& Sons.

Zulkifli. (2009). Psikologi Perkembangan. Bandung: PT. Remaja Rosdakarya. 